\title{
NORMATIVENRDERS
}

Cluster of Excellence at Goethe University Frankfurt/Main

\author{
Normative Orders Working Paper
}

$04 / 2011$

\section{Transnational Justice and Democracy}

Prof. Dr. Rainer Forst

Cluster of Excellence

The Formation of Normative Orders

www.normativeorders.net

Goethe-Universität Frankfurt am Main

Institut für Politikwissenschaft, Robert-Mayer-Straße 5, 60325 Frankfurt am Main

Rainer.Forst@normativeorders.net

(c) 2011 by the author(s) 


\title{
Transnational Justice and Democracy ${ }^{1}$
}

\author{
by Rainer Forst
}

\section{Three Dogmas of Political Theory}

The title I have chosen seems to signal a tension, even a contradiction, in a number of respects. Democracy appears to be a form of political organisation and government in which, through general and public participatory procedures, a sufficiently legitimate political will is formed which acquires the force of law. Justice, by contrast, appears to be a value external to this context which is not so much linked to procedures of "input" or "throughput" legitimation but is understood instead as an output- or outcome-oriented concept. ${ }^{2}$ At times, justice is even understood as an otherworldly idea which, when transported into the Platonic cave, merely causes trouble and ends up as an undemocratic elite project. ${ }^{3}$ In methodological terms, too, this difference is sometimes signalled in terms of a contrast between a form of "worldly" political thought and "abstract" and otherworldly philosophical reflection on justice. ${ }^{4}$

In my view, we are bound to talk past the issues to be discussed under the heading "transnational justice and democracy" unless we first root out false

\footnotetext{
${ }^{1}$ I presented earlier versions of this paper at the General Conference of the German Association of Political Science in Kiel in September 2009, at the Final Conference of the Research Project on "Transnational Justice and Democracy” of the Frankfurt Cluster of Excellence “The Formation of Normative Orders” in Bad Homburg in September 2010, at the Recon Workshop on "The European Political Order: State-less but Democratic and Just?” in Oslo in September/October 2010, at the Annual Meeting of the Eastern Division of the American Philosophical Association in Boston in December 2010, in the Political Theory Colloquium in Frankfurt in January 2011 and in the Colloquium in Legal and Social Philosophy at University College London in February 2011. I owe special thanks to the collaborators in these research projects and to the commentators on this paper, in particular to Jürgen Neyer, Klaus Schlichte, Nicole Deitelhoff, Peter Niesen, Klaus Dieter Wolf, Ayelet Banai, Rainer Schmalz-Bruns, Erik O. Eriksen, John Erik Fossum, Kjartan Koch Mikalsen, Daniel Gaus, Ken Baynes, Seyla Benhabib, Stefan Gosepath, Julian Culp, Franziska Dübgen, Christian Volk, Dorothea Gädeke, Enrico Zoffoli, George Letsas and John Tasioulas.

${ }^{2}$ For example, see Jürgen Neyer, “Justice, not democracy,” in: Rainer Forst and Rainer Schmalz-Bruns (eds), Political Legitimacy and Democracy in Transnational Perspective, Recon Report (Oslo: Arena, forthcoming); and my reply in the same volume: "Justice and democracy. Comment on Jürgen Neyer."

${ }^{3}$ Ingeborg Maus, “Der Urzustand,” in Otfried Höffe (ed.), John Rawls. Eine Theorie der Gerechtigkeit (Berlin: Akademie, 1998); Harald Müller, Wie kann eine neue Weltordnung aussehen? (Frankfurt/Main: Fischer, 2008).

${ }^{4}$ Michael Walzer, Interpretation and Social Criticism (Cambridge, Mass.: Harvard, 1987).
} 
dichotomies such as the ones mentioned. My thesis will be that justice must be "secularised" or "grounded" both with regard to how we understand it and to its application to relations beyond the state. This thesis clashes with certain erroneous dogmas in political theory, to begin with:

1. the dogma of the essential difference between democracy and justice and their potential political incompatibility.

Overcoming this assumption in order to develop a theory of transnational justice and democracy is only one step in the argument. For such a theory also makes it necessary to question two further premises which restrict the scope of both justice and democracy, namely

2. the dogma that the necessary preconditions of a "context of justice" can be satisfied only within the confines of a state and

3. the dogma that democracy must take the form of a practice of a demos organised within a state.

I will begin with a discussion of the first dogma.

\section{Two Pictures of Justice}

Let me begin with a brief reference to Wittgenstein. In the Philosophical Investigations, he writes: "A picture held us captive. And we could not get outside it, for it lay in our language and language seemed to repeat it to us inexorably." ${ }^{5}$ । believe that reflection on justice is all too often held captive by a specific, unpolitical picture which rests on a particular interpretation of the ancient principle "To each his own" (suum cuique). This principle, which has been central to our understanding of justice since Plato, is interpreted in such a way that the primary issue is what goods individuals receive or deserve as a matter of justice - in other words, the primary issue is who "gets" what. The search for answers leads either to comparisons between the collections of goods people possess and points to relative conclusions; or one asks whether individuals have "enough" of the goods which are vital for leading a good life or one befitting a human being, irrespective of comparisons.

\footnotetext{
${ }^{5}$ Ludwig Wittgenstein, Philosophical Investigations, trans. G. E. M. Anscombe (Oxford: Blackwell, 1978), p. 48e (§ 115).
} 
Granted, these goods- and distribution-centred, recipient-oriented points of view have their point, for distributive justice is, of course, a matter of allocating goods; nevertheless this picture conceals essential aspects of justice - in the first place, the question of how the goods to be distributed come "into the world," thus questions of production and its just organization. Furthermore, secondly, this picture ignores the political question of who determines the structures of production and distribution and how, as though there could be a huge distribution machine that only needed to be programmed correctly. ${ }^{6}$ But not only would such a machine be problematic, because it would mean that justice would no longer be understood as an accomplishment of the subjects themselves but would turn them instead into passive recipients; this idea also neglects, thirdly, the insight that justified claims to goods do not simply "exist" but can only be ascertained discursively through corresponding justification procedures in which - and this is the fundamental requirement of justice - all are involved as free and equal individuals.

Finally, in the fourth place, the goods-fixated view of justice also largely ignores the question of injustice; for, by concentrating on overcoming deficiencies of goods, it treats someone who is deprived of goods and resources as a result of a natural catastrophe as equivalent to someone who experiences the same deprivation as a result of economic or political exploitation. It is true that assistance is appropriate in both cases. However, as I understand the grammar of justice, in the one case it is required as an act of moral solidarity, but in the other as an act of justice conditioned by the nature of one's involvement in relations of exploitation and injustice ${ }^{7}$ and the specific wrong in question. Ignoring this difference can lead one to mistake what is actually a requirement of justice for an act of generous "aid."

For the reasons cited, it is necessary, especially when dealing with questions of distributive justice, to recognize the political point of justice and to liberate oneself

\footnotetext{
${ }^{6}$ For the first two points, see especially Iris Young, Justice and the Politics of Difference (Princeton: Princeton University Press, 1990), and my "Radical Justice: On Iris Marion Young's Critique of the 'Distributive Paradigm',” Constellations 14, 2007, pp. 260-65.

${ }^{7}$ Here a whole series of cases would have to be distinguished: direct participation in or (joint) causation of injustice; indirect participation in injustice by profiting from it, without oneself actively contributing to relations of exploitation; and the ("natural”) duty to put an end to unjust relations, even if one does not profit from them but possesses the means to overcome them.

${ }^{8}$ See my “A Dialectic of Morality," in Andreas Follesdal and Thomas Pogge (eds), Real World Justice

(Dordrecht: Springer, 2005), pp. 27-36.
} 
from a false and reified picture which is focused solely on quantities of goods. On the contrary, if we follow a second, more appropriate picture, justice should aim at intersubjective relations and structures, not at subjective or supposedly objective states of the provision of goods. Only by thus taking into consideration the first question of justice - namely, the justifiability of social relations and, correspondingly, of how much "justificatory power" individuals or groups have in a political context does a radical, critical conception of justice become possible, one which gets at the roots of relations of injustice.

\section{The Right to Justification}

Here we must first ask what justifies us in speaking of a "false" as opposed to a more "appropriate" picture of justice; for after all, the goods- or recipient-centred understanding can appeal to the time-honoured principle suum cuique. Is there a more original, deeper meaning of justice than this? In my opinion there is. The concept of justice possesses a core meaning to which the essential contrasting concept is that of arbitrariness, ${ }^{9}$ understood in a social sense, whether it assumes the form of arbitrary rule by individuals or by part of the community (for example, a class) over others, or of the acceptance of social contingencies which lead to asymmetrical positions or relations of domination and are defended and accepted as an unalterable fate, even though they are nothing of the sort. Arbitrary rule is the rule of some people over others without legitimate reason, i.e., domination, and where struggles are conducted against injustice they are first and foremost directed against forms of domination of this kind. The underlying impulse that opposes injustice is not primarily that of wanting something, or more of something, but of not wanting to be dominated, harassed or overruled any longer in one's claim and basic right to justification. This claim involves the demand that no political or social relations should exist which cannot be adequately justified towards those involved. Herein resides the

\footnotetext{
${ }^{9}$ See also Rawls's definition in A Theory of Justice, rev. ed. (Cambridge, Mass.: Harvard University Press, 1999), p. 5. For a discussion of arbitrariness and a critique of Philip Pettit's important view in his Republicanism (Oxford: Oxford University Press, 1997), see Henry Richardson, Democratic Autonomy (Oxford: Oxford University Press, 2002), ch. 3. I cannot go into this here, but I prefer to explain arbitrariness by way of an account of justice and justification rather than liberty, mainly because only by having recourse to certain criteria of justification can one explain which encroachments on liberty are justifiable and which are not.
} 
profoundly political essence of justice which the principle suum cuique not only fails to grasp but tends to conceal; for justice is a matter of who determines who receives what - thus the dimension which in Plato is represented by the idea of the Good or by the philosopher king. In my picture, the demand for justice is an emancipatory one; reflexively speaking, it rests on the claim to be respected as a subject of justification, that is, to be respected in one's dignity as a being who can provide and demand justifications. The person who lacks certain goods should not be regarded as the primary victim of injustice but the one who does not "count" in the production and allocation of goods.

\section{Egalitarian Theories}

One can cut different paths through contemporary discussions on justice. However the one opened up by the question of the two pictures of justice is especially instructive, for from this perspective certain adversaries unexpectedly find themselves in the same boat.

An example is provided by the recent debate concerning equality. By this is actually meant two points of discussion: on the one hand, the question "Equality of what?" - of resources, welfare, or capabilities ${ }^{10}$ - and, on the other, the question "Why equality at all?" From the perspective of the difference between the two pictures of justice, however, it becomes apparent that both the advocates and the opponents of equality frequently operate with the same understanding, and this often even finds expression in a specific image, that of the goddess Justitia as a mother who has to divide up a cake and asks herself how this should be done. ${ }^{11}$ Egalitarians argue for the primacy of the equal distribution of goods, according to which other arguments for legitimate unequal distributions - for instance, ones based on need, merit or prior claims - then have to be treated as special reasons. Alternatively, an egalitarian calculus of need satisfaction - welfare - is posited which serves as the goal of

\footnotetext{
10 See, especially, Gerald Cohen, “Equality of What? On Welfare, Goods, and Capabilities,” in Martha Nussbaum und Amartya Sen (eds.), The Quality of Life (Oxford: Oxford University Press, 1993), pp. 9-29.

${ }^{11}$ See, for example, Ernst Tugendhat, Vorlesungen über Ethik (Frankfurt am Main: Suhrkamp, 1993), pp. 373f.; Wilfried Hinsch, Gerechtfertigte Ungleichheiten (Berlin: de Gruyter, 2002), p. 169f.; Stefan Gosepath, Gleiche Gerechtigkeit (Frankfurt am Main: Suhrkamp, 2004), p. 250ff. The cake example, though without the mother, can also be found in Isaiah Berlin, "Equality “, in Concepts and Categories, H. Hardy (ed.) (Harmondsworth: Penguin, 1981), p. 84.
} 
distribution. ${ }^{12}$ However in the process the question of how the cake was produced and, even more important, who gets to play the role of the mother remains largely unthematized. Yet that is the principal question of justice.

\section{Critics of Equality}

Analogous problems are found on the side of the critics of equality. In Harry

Frankfurt's view, for example, the defenders of egalitarian conceptions of justice cannot be concerned with the value of equality at all; for if you ask them what is so bad about inequality, they respond by pointing to the negative consequences of living conditions in a society of inequality, in particular to the fact that certain people lack important goods for a satisfactory life. ${ }^{13}$

So-called "sufficientarians"14 have taken up these arguments and argue that "at least the especially important, elementary standards of justice are of a nonrelational kind,"15 and that justice is concerned with creating "conditions of life befitting human beings" that can be measured according to "absolute standards of fulfilment," not according to what others have. On this view, a universal conception of the goods "necessary for a good life" should be produced with reference to particular lists of basic goods.

These approaches are also open to serious objections. Thus Frankfurt's assertion that the pivotal issue is not how much others have but only whether I have "enough," is valid only when conditions of background justice pertain, that is only when others have not previously taken advantage of me. Hence we must look for reasons for such background justice elsewhere.

But, in addition, the idea of "having enough" or "getting enough" does not get at the essence of justice, i.e. the prevention of social domination. Justice is always a

\footnotetext{
12 This is especially true of "luck egalitarianism.” For a paradigmatic expression, see Richard Arneson, "Luck Egalitarianism: An Interpretation and Defense,” Philosophical Topics 32 (2004): 1-20 and "Luck and Equality,” Proceedings of the Aristotelian Society, suppl. vol. (2001), 73-90. For a critique see Elisabeth Anderson, "What is the Point of Equality?” Ethics 109 (1999): 287-337.

13 Harry Frankfurt, "Equality as a Moral Ideal,” in The Importance of What we Care About (Cambridge:

Cambridge University Press, 1988), pp. 143-58, and “Equality and Respect," in Necessity, Volition, and Love (Cambridge: Cambridge University Press, 1999), pp. 146-54.

${ }^{14}$ Roger Crisp, “Equality, Priority, and Compassion,” Ethics 113, 2003: 745-63.

15 Angelika Krebs, "Einleitung: Die neue Egalitarismuskritik im Überblick “, in Krebs (ed.), Gleichheit oder Gerechtigkeit (Frankfurt am Main: Suhrkamp, 2000), pp. 17f.
} 
"relational" matter; it does not first inquire into subjective or objective states of affairs but into relations between human beings and what they owe to each other for what reasons. In particular, we do not explain the requirements of justice on the model of morally required aid in specific situations of want or need; instead they come into play in situations where what is at stake are relations between human beings that are fundamentally in need of justification, where those involved are connected by social relations of cooperation in the production and distribution of goods - or, as is mostly the case, by relations of "negative cooperation ", of coercion or domination (whether by legal, economic or political means). It makes a huge difference whether someone is deprived of certain goods and opportunities unjustly and without justification or whether he or she, for whatever reason, lacks certain goods (for example, as a result of a natural catastrophe, as mentioned above). By losing sight of the former context, one misses or conceals the problem of justice as well as that of injustice. Justice requires that those involved in a context of (positive or negative) cooperation should be respected as equals. That means that they should enjoy equal rights to take part in the social and political order of justification in which the conditions under which goods are produced and distributed are determined.

\section{The First Question of Justice}

Let us review the essential points thus far from a constructive perspective. I have defined justice as the human capacity to oppose relations of arbitrary rule or domination. Domination is rule "without justification" and it is assumed that a just social order is one to which free and equal persons could give their assent - not just their counterfactual assent but assent based on institutionalised justification procedures. This is a recursive implication of the fact that what is at stake in political and social justice is norms of an institutional basic structure which claims reciprocal and universal validity. Thus a supreme principle holds within such a framework, namely the principle of general and reciprocal justification, which states that every claim to goods, rights or liberties must be justified in a reciprocal and general manner, where one side may not simply project its reasons onto the other but has to justify itself discursively.

This brings us to the central insight for the problem of political and social justice, namely that the first question of justice is the question of power. For justice is not only a matter of which goods, for which reasons and in what amounts should 
legitimately be allocated to whom, but in particular of how these goods come into the world in the first place and of who decides on their allocation and how this allocation is made. Theories of a predominantly allocative-distributive kind are accordingly "oblivious to power" insofar as they conceive of justice exclusively from the "recipient side," and if necessary call for "redistributions," without emphasizing the political question of how the structures of production and allocation of goods are determined in the first place. The claim that the question of power is the first question of justice means that justice has its proper place where the central justifications for a social basic structure must be provided and the institutional ground rules are laid down which determine social life from the bottom up. Everything depends, if you will, on the relations of justification within a society. Power, understood as the effective "justificatory power" of individuals, is the higher-level good of justice. ${ }^{16}$ It is the "discursive" power to demand and provide justifications and to challenge false legitimations. This amounts to an argument for a "political turn" in the debate concerning justice and for a critical theory of justice as a critique of relations of justification. ${ }^{17}$

A comprehensive theory of political and social justice should be constructed on this basis, something at which I can only hint here. ${ }^{18}$ First we must make a conceptual distinction between fundamental (minimal) and full (maximal) justice. Whereas the task of fundamental justice is to construct a basic structure of justification, the task of full justice is to construct a justified basic structure. The former is necessary in order to pursue the latter, that is, a "putting-into-effect" of justification through constructive, discursive democratic procedures in which the "justificatory power" is distributed as evenly as possible among the citizens. In spite of the appearance of paradox, this means that fundamental justice is a substantive starting point of procedural justice. Based on a moral right to justification, arguments are presented for the basic structure in which those who are part of it have real

\footnotetext{
${ }^{16}$ Power is a kind of good that cannot be distributed like a material good, as Iris Young argued in Justice and the Politics of Difference, ch. 1. But resources that help to generate power can be distributed, such as means of education and information and access to public communication; other such goods are social and political positions. I discuss the concept of power in my "Noumenal Power”, Ms.

${ }^{17}$ See Forst, Justification and Critique (Cambridge: Polity, forthcoming).

${ }^{18}$ For a more detailed discussion see Forst, Contexts of Justice and The Right to Justification.
} 
opportunities to codetermine the institutions of this structure in a reciprocal and general manner. Fundamental justice guarantees all citizens an effective status "as equals ".

\section{Transnational Contexts of Justice and Justification}

Once the first dogma of recipient- and outcome-centred justice and the assumed incompatibility between justice and democracy which rests on that picture of justice has been surmounted, the path leading beyond the two other dogmas is already marked out. For it became clear that justice presupposes in the first instance specific practices of justification - within a basic structure of justification - and that this praxis is what we mean by democracy: those who are subject to norms should also be the authority which justifies these very norms - as active subjects of justification and not just in mente or in proxy or expert discourses. ${ }^{19}$ The goddess Justitia does not come into the world to dispense gifts; her task is instead to banish arbitrary rule, i.e. domination. Democracy is the best possible form of political order to accomplish this and to secure the political autonomy of those who are supposed to be both subjects and authors of the law - in accordance with their dignity as autonomous subjects of justification. $^{20}$

How should this result be interpreted in the transnational context? Let us first consider the position - the second false dogma - which asserts that only a state context can provide the preconditions for localising - i.e., grounding and realizing justice. As I said, the proper place of justice is where a threat of arbitrary rule exists, where a context of cooperation could be or is degenerating into a context of domination. Thus, one might conclude, the existence of a certain context of social cooperation is an unavoidable precondition for a context of justice.

A number of theories have drawn this conclusion. In the first place, we must mention that of John Rawls. For his point of view - which leads him to locate social

\footnotetext{
${ }^{19}$ This marks a basic point of disagreement between Jürgen Neyer’s view and mine. See Neyer, “Justice, not Democracy: Legitimacy in the European Union,” and my “Justice and Democracy: Comments on J. Neyer, 'Justice, not Democracy',” both in: Rainer Forst and Rainer Schmalz-Bruns (eds), Political Legitimacy and Democracy in Transnational Perspective, Recon Report, Oslo: Arena, 2011.

${ }^{20}$ See my "The Grounds of Critique. On the Concept of Human Dignity in Social Orders of Justification,” tr. Ciaran Cronin, Philosophy and Social Criticism, forthcoming.
} 
justice in the national sphere and to regard the international domain as one in which certain (minimal) human rights are valid and otherwise only duties of assistance ${ }^{21}$ is not so much a state-centred as a cooperation-centred one. It is often underestimated how much weight Rawls attaches to the "most fundamental" idea of a "society as a fair system of social cooperation over time from one generation to the next," which he consistently situates at the centre of his theory. ${ }^{22}$ According to Rawls, only such a society provides the resources - in the twofold sense of material and normative resources - which are the presupposition for a "well-ordered society." Only here are the reciprocity conditions and the social cohesion - economic, political and moral - which a just society requires to be found.

Some theories develop this idea in a more communitarian direction, so that "common sentiments" or "shared understandings" within a nation become the essential presupposition for a context of justice, ${ }^{23}$ others, by contrast, highlight the state as the central context. Thomas Nagel expresses this as follows: "Justice is something we owe through our shared institutions only to those with whom we stand in a strong political relation. It is, in the standard terminology, an associative obligation." ${ }^{24}$ The essential aspects of such a "strong political relation" are the existence of a collectively authorised source of law and the non-voluntariness of the relation - that is, that the law expresses the will of the citizens (or at least claims to do so) and that this must also be the case, normatively speaking, if citizens are not to be subjected to external constraints without adequate justification. Positive normative authority and factual coercion must coexist in order to form to a context of justice.

The arguments of Rawls and Nagel carry considerable weight because on a relational view a context of justice is in fact a particular context of social and political relations which gives rise to special demands. Nevertheless these approaches are problematic because they use a conclusion as a premise when they argue that a particular institutional context of social cooperation or a political community is a

\footnotetext{
${ }^{21}$ See John Rawls, The Law of Peoples (Cambridge: Harvard University Press, 1999).

22 John Rawls, Justice as Fairness: A Restatement, ed. Erin Kelly (Cambridge: Cambridge University Press, 2001), p. 5. See also Rawls, A Theory of Justice, p. 9: "Fully to understand a conception of justice we must make explicit the conception of social cooperation from which it derives."

${ }^{23}$ David Miller, National Responsibility and Global Justice (Oxford: Oxford University Press, 2007), Michael Walzer, Spheres of Justice (New York: Basic Books, 1983).

${ }^{24}$ Thomas Nagel, “The Problem of Global Justice,” Philosophy and Public Affairs 33, 2005: 113-47, here p. 121.
} 
necessary precondition of the application of the concept of social or political justice. As explained above, Justitia is a man-made deity who comes into the world to banish social arbitrariness, and this means that she has her (combative) place were arbitrariness prevails among human beings or where it is a possibility. In such cases she calls for specific institutions, for example - traditionally speaking - for the rule of law where the "state of nature" existed; but then she cannot presuppose these institutions of justice. She presupposes the status of persons as beings who have a right to justification and she demands that a basic structure of justification be constructed where arbitrary rule has to be excluded; but she does not demand this only where a positive (i.e. legally constituted) institutional basic structure of positive (i.e. mutually beneficial) cooperation already exists. Thus we do not have to object to Rawls, as certain globalist cosmopolitans assume, that a "global basic structure" already in fact exists comparable to a national one,${ }^{25}$ since this is a competition that cosmopolitans can hardly win; nor do we need to object to Nagel that global governance institutions also exercise legal coercion and claim authority for this (though this is an important argument to make). ${ }^{26}$ Instead we have to go beyond any dichotomous thinking in terms of "state" vs. "world" and accept the existence of a plurality of different contexts of social and structural justice (as contexts of political or social rule) or injustice (as contexts of domination) and thereby correctly situate or "ground" justice - informed by an appropriate and "realistic" social-scientific analysis of "what is." 27

Such a "practice-dependent" approach to justice, to use Andrea Sangiovanni's apt phrase, ${ }^{28}$ though in a different sense from his, would imply that a context of political or social justice exists wherever social (or legal or political) relations with a structure of cooperation in some minimally stable form exist. But this importantly includes, besides positive cooperation, negative cooperation, i.e. forms of

\footnotetext{
${ }^{25}$ See the original (and later differentiated) view of Charles Beitz in his Political Theory and International Relations (Princeton: Princeton University Press, 1979), Pt. 3, and Thomas Pogge, Realizing Rawls (Ithaca: Cornell University Press, 1989), Ch. 6.

${ }^{26}$ See Joshua Cohen and Charles Sabel, “Extra Rempublicam Nulla Justitia?,” Philosophy and Public Affairs 34, 2006: 147-75.

${ }^{27}$ Here I draw on my argument in “Towards a Critical Theory of Transnational Justice,” in: Metaphilosophy 32, 2001: 160-79, reprinted in Thomas Pogge (ed.), Global Justice (Oxford: Blackwell, 2001), pp. 169-87.

${ }^{28}$ Andrea Sangiovanni, “Justice and the Priority of Politics to Morality,” The Journal of Political Philosophy 16, 2008, pp. 137-64.
} 
unjustifiable coercion and of exploitation, in short, domination; and it is hard to dispute that such forms of social or political domination exist at the transnational level even in our "postcolonial" times. ${ }^{29}$ Here a complex system of asymmetry and its reproduction exists with numerous structures and relations in need of justification. This is why, reflexively speaking, the first task of justice would be to construct transnational structures of justification - structures which would have to be concrete enough to turn relations of domination into relations of justification and general enough to leave room for disputes and contestation concerning the analysis and evaluation of existing social relations and structures. ${ }^{30}$ Justice tracks, as it were, arbitrariness and forms of domination and coercion wherever they occur. The assumption that this would first require an already existing positive, institutional social or legal context of cooperation fails to grasp the correct order of things: the first thing is injustice (i.e. asymmetrical social relations without justification) in the world and then justice calls for structures of justification and banishes human arbitrariness. . Political and social justice is a relational as well as an institutional virtue; it does not refer to all relations between human beings, but to those which exhibit forms of positive rule or forms of domination - whether in the state or in the "state of nature," in the national or the international or the transnational domain in general.

With respect to "practice-dependence," we thus need to distinguish between positive and negative practice-dependence. The positive version refers to already established forms of rule and coercion by the state, or at least by legal institutions which claim normative authority and always harbour the danger that arbitrariness distorts given forms of cooperation. The negative version, by contrast, refers to forms of domination in need of justification and institutional "taming"; thus these practices are not sufficiently institutionalized. Positive practice-dependence comes in degrees, depending on the thickness of already institutionalized political and legal contexts,

\footnotetext{
${ }^{29}$ See the accounts in Andrew Hurrell, On Global Order. Power, Values and the Constitution of International Society (Oxford: Oxford University Press, 2007), and Deborah D. Avant, Martha Finnemore, Susan K. Sell (eds), Who Governs the Globe? (Cambridge: Cambridge University Press, 2010).

${ }^{30} \mathrm{I}$ am in agreement with Nancy Fraser, Scales of Justice. Reimagining Political Space in a Globalizing World (New York: Columbia University Press, 2009), esp. chs. 2 and 4, that the latter reflexive dimension is important; I think, however, that critical social analysis is capable of providing us with sufficient empirical knowledge about existing relations and structures without justification to locate substantive demands of fundamental justice.
} 
and so does domination, whether it be of an economic, a cultural or a political kind. But both practices mark contexts of justice.

Connected with the distinction between positive and negative practicedependence is another important one which one-sided views of positive practicedependence do not sufficiently pay tribute to, though it plays a role in their argument: there are institutions necessary to realize justice, depending on context, and there are practices and institutions which make justice necessary - in a way, they "call for" justice. ${ }^{31}$ Call these justice-realizing and justice-necessitating practices and institutions. It is a mistake to identify the two, for that would mean that we could not refer to injustice or the demand for justice outside of already established institutions. As the classic theorists of natural right argued, the injustice of the "state of nature" i.e. the arbitrary rule of some over others in a pre-institutional form - or of the already established state - such as a monarchy according to Filmer's patriarchal view ${ }^{32}$ or the rule of the rich in Rousseau's Second Discourse ${ }^{33}$ - both needed to be overcome by establishing a just and legitimate political order. The first task to be accomplished to that end must be to establish a sufficient order of justification such that those subjected by positive forms of rule or "wild" forms of domination are no longer just objects but also subjects, i.e. they become autonomous normative authorities. Following Kant and at the same time going beyond his idea of the only "innate" or "original" (angeboren) right of human beings, ${ }^{34}$ the "ultimate" ground for this idea of justice-generating practices of justification is the basic human right to justification i.e. the right which protects against being forced to live under institutions or being subjected to norms that cannot properly be justified towards those subjected as free and equal agents of justification. This is a reflexive right which calls for certain practices of justification in the sense of fundamental justice.

If it were possible to reconstruct the respective existing positive and negative contexts of rule, domination and coercion adequately, this would already go a long

\footnotetext{
${ }^{31}$ See, for example, Sangiovanni, “Justice and the Priority of Politics to Morality,” pp. 137 and 159.

${ }^{32}$ As famously criticized in Locke's First Treatise of Government.

${ }^{33}$ Jean-Jacques Rousseau, Discourse on the Origin of Inequality, tr. F. Philip (Oxford: Oxford University Press, 2009).

${ }^{34}$ Immanuel Kant, The Metaphysics of Morals, tr. M. Gregor (Cambridge: Cambridge University Press, 1996), $6: 237$ (30).
} 
way towards answering the question concerning the contexts of justice. However, the complexity of Justitia would then become especially apparent because the corresponding basic structures of justification - from the state to the globe - would have to track these different contexts. This is why justice is still, in some sense, a goddess or a context-transcending idea, but one which does not do the work for us; we have to do it ourselves, as political and reflexive agents.

\section{Demoi of subjection and justification}

A critical theory of transnational justice does not paint an idealised image of perfect global distribution as an "end state" (Nozick), nor does it proceed from an "original position" involving all human beings. Instead it has a contextual starting point, for it traces the actually existing relations of positive rule and of domination and exploitation, of structural asymmetries and arbitrary rule, in order to call for the establishment of relations of justification, and hence of justifiability, wherever they are encountered. This opens up a complex panorama of relations, structures, actors and necessary institutions which appears highly confusing. . The important point, however, is that justice tracks injustice, and hence the question '"world state' or 'world of states'?" is not the primary concern from the perspective of justice. At some point we need to consider what form the structures of justification would have to assume in order to tame domination through transnational and international institutions, but before that kind of construction the first task is the "realistic" reconstruction of relations of domination.

As a consequence, the first constructive task of justice is to produce structures in which arbitrary rule is banished and fair relations of justification are realised structures in which those who are exposed to rule or domination, whether of an economic, a political or a legal kind, can bring the "coercion towards the better argument" (to modify a formulation by Habermas) to bear against those who exercise such rule or domination. This is where democracy comes into play, to turn to the third dogma of political theory in this connection, which asserts that democracy calls for a demos organized within a state. Democracy, as I said above, is the term for a normative order in which those who are subject to binding legal norms should also be the normative authority that deliberates and decides about these norms, in an active sense in the context of a practice of justification. We are familiar with democratic normative orders within which different forms of such practices of justification exist, 
and we also know that they are riven by incessant conflicts over whether they can redeem their claim to justification. One need only think of issues like campaign financing, the 5\% hurdle, plebiscites, and the like. Such sites and institutions also exist at the transnational and international levels, though they mostly remain at levels of development which, as in the case of the UN, reflect the post-war balance of power or simply global relations of economic power.

If we understand democracy in such a way that it seeks to subsume the exercise of rule or domination under relations of effective justification and authorisation of norms by those who are subject to them, then the assumption that this requires a definite and single demos is problematic. For the demoi which are constituted as states are already integrated into such diverse networks of international and transnational rule or domination, formal and informal, that the "congruence condition" (Zürn) ${ }^{35}$ of the authorisation and legitimate exercise of rule is no longer satisfied in a number of ways. There are demoi which, to simplify, are subjected to external power in different ways, and there are demoi which profit from such subjection - and there are hybrid forms of the two. But more than that, if we heed the principle of turning those subjected into agents with normative authority, it is questionable whether the existing demoi within state borders are generally the main or the only agents of justice and democracy. ${ }^{36}$ Justice, and with it democracy, are recuperative institutions, not ones which found institutions ex nihilo; demoi constitute themselves through existing relations of rule or domination - which transcend state borders in more than one way constituting new social and political agents within and beyond existing polities.

In my view, processes of political recuperation already merit the title "democratic" when they succeed in creating effective relations of justification that curb domination, for instance through effective contestation, ${ }^{37}$ even if they remain a

\footnotetext{
${ }^{35}$ Michael Zürn, Regieren jenseits des Nationalstaats (Frankfurt/Main: Suhrkamp, 1998), p. 17.

${ }^{36}$ Despite important agreements with the view of James Bohman, Democracy across Borders: From demos to demoi (Cambridge, Mass.: MIT Press, 2007), we differ over how far the notion of demoi needs to be redefined according to existing relations of domination that transcend existing polities. In his federalist view, these remain the essential political agents forming higher-order political entities such as the EU.

${ }^{37}$ See Philip Pettit, “Democracy, National and International”, The Monist 89, 2006: 301-24. I do not follow Pettit's sharp distinction between an "authorial” and an "editorial” notion of democratic control; in order to be
} 
step removed from complete recuperation and containment. A global constitutionalisation such as that proposed by Jürgen Habermas is not global democracy, much less deliberative democracy, in the guise of a world state. ${ }^{38}$ But wherever the privileged are forced to renounce their prerogatives because, having been exposed, the ground has been pulled out from under them and justifiable counterpower is being mobilised - wherever this occurs and relations of justification are established which reclaim normative authority it marks an increase in democracy. The difference from attempts at democratization within societies such as ours can be large, but it seems to me to be a matter of degree, not of kind. Democracy progresses - often only in modest steps - where arbitrary and insufficiently justified rule, whether it be political, legal or economic, is exposed and ultimately subjected to the justificatory authority of those affected. This is a question of justice - the question of justice.

Such practices of justice are no more confined to the long-established institutions and political ways of thinking than are the relations of domination to which persons all over the world are exposed. In political theory, we have to think of justice and democracy in terms of processes of recuperation and of the increase of relations of justification, not in terms of fixed and narrow ideals. For democracy and justice are ultimately autonomous practices which create their own forms.

\section{Two Pictures of Europe}

The essential lesson that follows from this for thinking about democracy and justice within the European Union is that we should be sceptical of free-standing conceptions of its telos or finalité. Realistically speaking, the EU has grown into a powerful supranational, international and transnational polity sui generis, which means that the question of its legitimacy needs to be answered in a reflexive and democratic way, ${ }^{39}$ but such that the main focus is on the power-relations within and

democratic, a basic structure of justification has to contain both elements, combined within practices of justification. Only in that way can domination be structurally avoided.

${ }^{38}$ Jürgen Habermas, “Does the Cosmopolitanization of International Law Still Have a Chance?”, in The Divided West (Cambridge: Polity, 2006), pp. 115-93.

${ }^{39}$ As emphasized by Erik O. Eriksen, The Unfinished Democratization of Europe (Oxford: Oxford University Press, 2009); Bohman, Democracy across Borders, Ch. 4, and Rainer Schmalz-Bruns, “Democratic Legitimacy, 
beyond this entity. ${ }^{40}$ The famous "legitimation question" is the question of which structures of justification need to be established in order to recuperate - i.e. tame and legitimise - the exercise and effects of power, rule and domination which exist on the various regional, national and transnational levels. Within the legal realm of the EU, this is already a Herculean task, but it is even more so with respect to the equally important dimension of the relations between the EU and states, institutions and persons outside its jurisdiction which form various demoi of subjection. How it deals with migrants, neighbouring states and the many regions of the world it affects (and sometimes dominates) through its policies, be they agricultural or ecological, for example, will also determine whether it can claim to be a just polity.

If we think back to the two pictures of justice with which I began, an alternative opens up for the EU as a political project. For it is quite possible that it will not develop in the direction called for by the second, apt picture of justice, but that it will become a model for a transnational polity according to the first picture. This would mean that democratic justice would be sacrificed for certain levels of the provision of goods and that such output, even if unequally distributed, would be seen as providing it with legitimacy. That would go along with an increase in the standard of living for many as well as further elitist and technocratic forms of rule, not to mention internal and external domination. Thus it would represent a diminution of politics on a large scale - especially so if the citizens of Europe did not even regard these pictures as a basic alternative.

Translated by Ciaran Cronin

Political Normativity and Statehood," in Erik O. Eriksen and John Erik Fossum (eds), What Democracy for Europe?, Recon Report No 11, Oslo: Arena, 2010, pp. 83-114.

${ }^{40}$ See James Tully, "A New Kind of Europe? Democratic Integration in the European Union," in Public Philosophy in a New Key (Cambridge: Cambridge University Press, 2008), pp. 225-42. 